\title{
Critical Issues to Be Concern In Selecting Tools for Teaching High School Computer Project Lesson Using Computer-Supported Collaborative Learning
}

\author{
Prapat Palacheewa ${ }^{1}$, Praweenya Suwannatthachote ${ }^{1}$, Prachyanun Nilsook ${ }^{2}$ \\ ${ }^{1}$ Faculty of Education, Chulalongkorn University, Bangkok, Thailand \\ ${ }^{2}$ Faculty of Technical Education Division of Information and Communication Technology for Education, \\ King Mongkut's University of Technology North Bangkok, Thailand \\ Email: tattoo_41@hotmail.com,praweenya@gmail.com, prachyanunn@gmail.com
}

Received 2012

\begin{abstract}
Project-based learning is activity that encourage learners to apply their knowledge from classroom to practice, Practice students to work as a team and enhance the learning potential of student. Computersupported collaborative learning are tools for help students in knowledge sharing, build the knowledge approach to teaching on constructivist. Therefore, principles of project-based learning and computersupported collaborative learning to the computer projects courses also train students to work with classmates. Use apply computer skill for problem solving or create product by step of project-based learning. This article aims to present critical issues that teacher should concern in computer project-based and techniques or method in the project-based learning and application of computer supported collaborative learning in the computer project. Which is opinion from specialist teachers in computer project. The results of this study is teacher should offer project work by clearly target. Teacher give individual work before group discussion then students are joint to group for share the ideas and develop project. Computer-sup- ported collaborative learning are tools for encourage students to develop project and actual solve the problems.
\end{abstract}

Keywords: Computer Project; Project-Based Learning; Computer-Supported Collaborative Learning

\section{Introduction}

Project-based learning is a teaching and learning activity focused on how students apply knowledge received from the classroom to solve the authentic problems or create product based on students: creativity. Computer project can be a group project or an individual project. The main objective of projectbased learning is to provide students to work collaboratively in a team, therefore, students interact and share ideas and knowledge with group members that consistent with a constructivist. The role of teachers changed to a facilitator and a consultant for students' project. Based on the vision of the future of education for $21^{\text {st }}$ century skills' "Teach less Learn more”, it does not mean that teachers have to teach less but teacher must provide more teaching methods and techniques to assist students to learn and practice from the authentic situation e.g. problem-based learning, case study, cooperative learning, and peer assessments.

When project-based learning is applied for a computer project in Thai secondary education, computer teachers follows four fixed steps as follows: 1) students create the project topic, 2) students propose the project proposal, 3) students develop the project following the proposal, and 4) students present the project. Those four steps are the broad basic that needs more students activities and teaching techniques to support students developing project effectively. Each learning step, teachers should encourage and focus on the students learning process such as discussion method. Students must prepare themselves for group discussion to identify the project topic. Teacher assigned students unclear on how to prepare themselves before discussing in the group and set the goal of discussion. Projectbased learning is a new teaching activity that was introduced for Thai education reform since 1999, but there was a lack of enough information for teachers in the curriculum and instruction handbook. Also, the computer teachers have less technological pedagogy knowledge and skills to integrate appropriate teaching method and technology to motivate and facilitate students work on computer project successfully. These are the obstacle for teachers and students for implementing the project-based learning in the computer project. This paper aimed to clarify on how to use project-based learning for the computer project in Thai secondary education. High teaching experienced teachers and the academic specialist from IPST were interviewed. Data from interview and document analysis were synthesized. Moreover, computer-supported collaborative learning is introduced as a learning tool. It also provides techniques in applying project-based learning and computer-supported collaborative learning in the computer project lesson from specialists and teachers.

\section{Review of Literature}

\section{Project-Based Learning}

Project-based learning model states on activities which students need to do complex tasks as projects. This leads students to build their own knowledge. (Jeremic, Jovanovic, Gaševic, and Hatala, 2009)

Project based learning strategy encourage students to do au- 
thentic tasks. Teachers give students projects or problems which are simulate professional situations. These strategies are student center approaches which teachers' role as facilitators. (Mettas and Constantinou, 2007)

Computer project lessons encourage students to learn and practice skills in using computer, software and tools to solve problems. The lessons also develop students' working attitude and their productions. Students are able to study any problem they are interested in. These can be problems which need computer knowledge. Some projects may need other fields of knowledge which students need to prepare in planning, studying, developing programs or related tools, and basic project skills.

\section{Computer-Supported Collaborative Learning (CSCL)}

Computer tools like multimedia and educational software are used in schools for community, computing and learning. (Andersson, 2008)

According to the use of collaborative learning, each learners can learn from group processes, collaboration and social interaction. Collaborative learning encourage learners to be interdependence in their learning process. (Cress, 2008)

Examples of computer-supported collaborative learning tools which can be used in communication between students are chat, Instant relay chat, Instant Messaging, Real time Audio, E-mail, WebBoard, Wiki, Weblog, Online Brainstorming, Online Argument, Online Mind mapping, etc.

\section{Data Collection}

To collect data, the author studied researches and documents about project based learning, computer projects and computer-supported collaborative learning. The authors also interviewed teachers who have experiences in teaching computer project lessons. Moreover, six lesson plans based on six stages of project based learning are designed for five experienced teachers and academic specialists to examine, correct and give suggestions.

\section{Critical Issues that Teachers should Concern in Teaching Computer Project Lesson}

Teacher can be to teach in each steps of the following.

\section{Selecting Topics of Interest}

The problem is that students usually don' know which project topic to be chosen. They cannot imagine the success or final products of the project. Therefore, teachers should follow these guidelines.

- Present a lot of examples of concrete projects so students can imagine the success of projects. For example, present the operations and the results.

- T Set a theme, a type, or a content of the projects so students will produce their projects in the same direction.

- Let students create project topics without concerning about the possibilities so students can express their ideas as much as possible.

\section{Document Reviews}

In this step students need to collect related information for their projects. Teachers should recommend resources for them.

\section{Preparing Project Proposals}

This step is a draft mind map of designing working processes, members' roles and the success of the project. In this step teachers should follow these guideline:

- Assess of possibilities and obstacles of the project so the students will be aware of the risks that lead their project to succeed or fail.

- If both teacher and students agree that the project tends to be failed, Students need to collect more information or start selecting a topic again. Teachers should give them advices so that the students do not have to start the process again and again.

\section{Developing Projects}

In this step, students develop the project proposal into practice follow the plan. Teacher should follow these guidelines.

- Guide and encourage them to complete the project.

- Provide meetings so that students are able to report their progress and problems. They will find solutions to solve these problems.

\section{Project Summary Report}

In this step, students report their process from the beginning to the end and also the results. These will be in any formats such as charts, graphs, etc., depend on the type of the project. Teachers should follow these guidelines.

- Prepare form report format which is suitable and covers all the topics to be presented. The printing format and references must be set.

- Prepare enough knowledge about how to present information in different ways, for examples, graphs, pie charts, line charts, images, etc.

\section{Present and Publish}

This is the last step which students present their results of the project. Students are able to present through media such as websites or exhibitions. The easiest way is to present in front of the class. The students may use presentation program with same descriptions. At the end, teachers should allow other students to ask questions. The teachers should randomly ask questions to the presenting group to check for the comprehensions.

The six steps of the project-based learning in the computer project lesson can be concluded as shown in Figure 1.

To be successful in every step of the project-based learning, it is found that there must be some discussion activities for students to find answers. Therefore, teachers should set the purposes or the contents for students at first. This will help students not to lose their ways and also save the time. For example, the purpose of the discussion is to choose only one topic which is the best or has a chance to be success for group project.

Besides from having effective discussions in limited time, teachers should assign students to study by themselves before discussions. The students will be able to discuss with their colleagues to find out the ways or agreements at the end of discussions for the next step. The processes of group discussion are in Figure 2.

Teachers can also use brainstorming technique or argument technique in the discussions.

Brainstorming technique encourages students to give as many ideas as they can in limited time. The more ideas are given, the better the discussions. There should be no criticisms or judgments. After that all the ideas are combined and considered to choose suitable solutions. The argument technique encourages 
students to find information which is accurate and reliable. Students give there opinions raise their strong points, and describe weak points of others' ideas.

The use of these two different techniques will provide different working environment. Brainstorming technique avoid the clashes of ideas. While brainstorming technique compromises members' ideas, argument technique points out the strong points and weak points of each ideas.

\section{Applying Computer-Supported Collaborative Learning for Computer Project Lessons}

Computer-supported collaborative learning is like an area for students to work together. They can exchange their ideas, look for solutions, and build knowledge. If teachers apply computersupported collaborative learning, it will support students to work in team.

To apply computer-supported collaborative learning, teachers should think of features and purposes of tools. Some tools in computer-supported collaborative learning are time synchronizing tools such as Chat, Internet Relay Chat, Instant Messaging, Real Time Audio. Others are asynchronizing tools, for example, E-mail, Webboard, wiki, Weblog, Online Brainstorming, Online Argument, Online Mindmapping. Some tools canbe web tools as in www.corkboard.me (Online Brainstorming), www.covinceme.com (Online Argument) and www.bubbl.us (Online Mindmapping)

Table 1 shows apply collaborative tools to each step of project development (Krogtie 2009) purposed a model of Retrospective Reflection in Project-Based Learning Utilizing Historical Data in collaborative tools into computer project course which apply tools to each step of project development.

Teachers are able to use these instant tools now. To select any computer-supported collaborative learning tools, teacher should consider contents, purposes, students and teaching techniques. For example in the step of selecting topics, teacher can use brainstorming technique through an online brainstorming tool. This helps students to see an overview of discussion and understand more in shorter time than a real discussion. Ti also decreases place and time limitation (Hermann and Nolte, 2010). Moreover, teachers can use Online Argument tools so students can find solutions in their group. It helps quiet and shy students to give more opinions in the discussion because they don't need to confront with other students. They have more time to think and consider about their ideas. Using these tools, students can avoid the confrontation between students who have different attitudes. Since computer-supported collaborative learning tools, like Online Brainstorming or Online Argument are web tools. These are the advantage and disadvantag

- No expenses : teachers and students can use the tools for free

- Easy to use : user interfaces are user friendly.

- Aesthetic design

- Appropriate for teachers to apply in project based learning : there are spaces foe students to share their ideas.

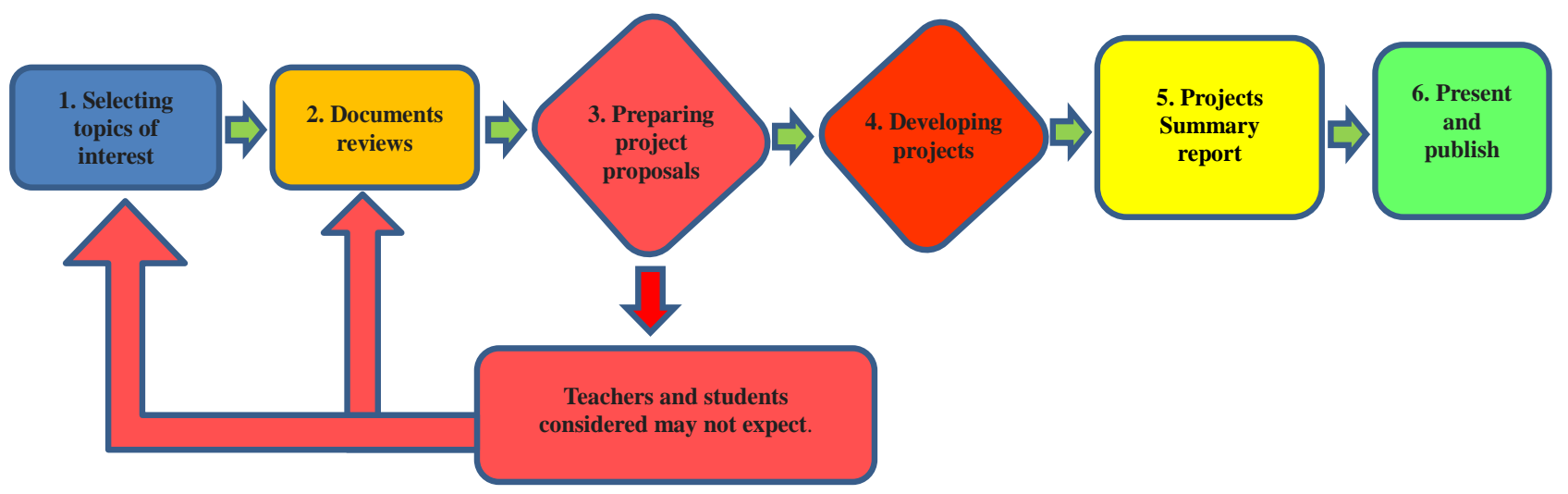

Figure 1.

The process of project-Based learning.

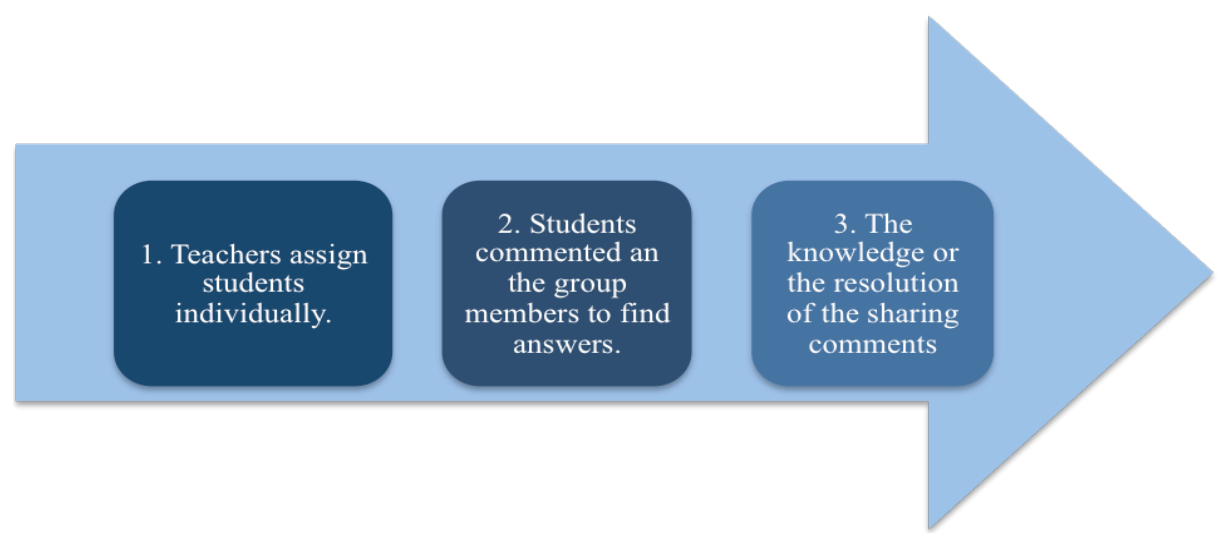

Figure 2.

The process of group discussion. 
Table 1.

Preview tools of computer -support collaborative learning tools.

\begin{tabular}{|c|c|c|}
\hline Research & $\begin{array}{l}\text { Used in the process of } \\
\text { Project-based learning }\end{array}$ & CSCL Contribute \\
\hline \multirow{7}{*}{$\begin{array}{l}\text { A Model of Retrospective Reflec- } \\
\text { tion in Project Based Leaming } \\
\text { Utilizing Historical Data in Col- } \\
\text { laborative Tools } \\
\text { Birgit R. Krogstie (2009) }\end{array}$} & Selected topics of interest & \multirow{7}{*}{$\begin{array}{l}\text {-Wikis or issue tracking tools are used for } \\
\text { managing team-internal coordination of tasks, e.g. create and follow up on } \\
\text { a project plan, and defime, assign and track the status of tasks. } \\
\text { - Development tools are used to write, test and } \\
\text { integrate source code. } \\
\text {-Email is used for formal and documented } \\
\text { sommunication intemally and in communication with other stakeholders. } \\
\text { - Instant messaging chat is used for informal, } \\
\text { team-internal messages and sub- stitute face-to-face conversation over } \\
\text { synchronous } \\
\text { - Internet sites are used to get information about } \\
\text { technology }\end{array}$} \\
\hline & Research documents & \\
\hline & Preparation of project proposals & \\
\hline & & \\
\hline & Development projects & \\
\hline & The projects summary report & \\
\hline & Present and publish & \\
\hline
\end{tabular}

Table 2.

Online Brainstroming Web tools.

\begin{tabular}{l} 
The criteria selection \\
Web tools \\
Onlime Brainstroming \\
\hline $\begin{array}{l}\text { https://bubbl.us/ } / \text { No expenses } \\
\text { http:/www.mindmeister.com } \\
\text { http://www.visual-mind.com } \\
\text { http:/www.brainreactions.net }\end{array}$
\end{tabular}

Table 3.

Online Argument Web tools.

Appropriate for
$\begin{aligned} & \text { The criteria selection } \\ & \text { teachers to apply in } \\ & \text { project based } \\ & \text { learning }\end{aligned}$

Author present examples of Online Brainstroming Web tools in Table 2 and examples of Online Argument Web tools in Table 3 below.

\section{Conclusion}

In conclusion to use computer-supported collaborative learning in computer project lesson is encourage students to work in a team. Students have more opportunities to share their ideas and knowledge. Teacher should consider contents, activity and students before selecting the collaborative tools.

\section{REFERENCES}

Andersson Lantz Annika. (2009). The power of natural frameworks: Technology and the question of agency in CSCL settings. Computer-Supported Collaborative Learning 4: pp. 93-107
Cress Ulrike. (2008). The need for considering multilevel analysis in CSCL research-An appeal for the use of more advanced statistical methods. Computer-Supported Collaborative Learning 3 : pp. 69-84

Herrmann Thomas and Nolte Alexander. (2010). The Integration of Collaborative Process Modeling andElectronic Brainstorming in Co-located Meetings. CRIWG 2, LNCS 6257, 145-60.

Jeremic Zoran, Jovanovic Jelena, Gaševic Dragan, and Hatala Marek. (2009). Project-Based Collaborative Learning Environment with Context-Aware Educational Services. U. Cress, V. Dimitrova, and M. Specht (Eds.): EC-TEL, LNCS 5794, pp. 441-446

Krogstie R. Birgit. (2009). A Model of Retrospective Reflection in Project Based Learning Utilizing Historical Data in Collaborative Tools. U. Cress, V. Dimitrova, and M. Specht (Eds.): EC-TEL, LNCS 5794, pp. 418-32

Mettas C. Alexandros and Constantinou C. Constantinos. (2007). The Technology Fair: a project-based learning approach for enhancing problem solving skills and interest in design and technology education. International Journal Technology Design Education 8: pp. 79-00 